\title{
Towards a Democratic Theory of the \\ World-System: Democracy, Territoriality, and \\ Transnationalization
}

Teivo Teivainen

\section{Journal of World-Systems Re search FESTSCHRIFT FOR IMMANUEL WALLERSTEIN}

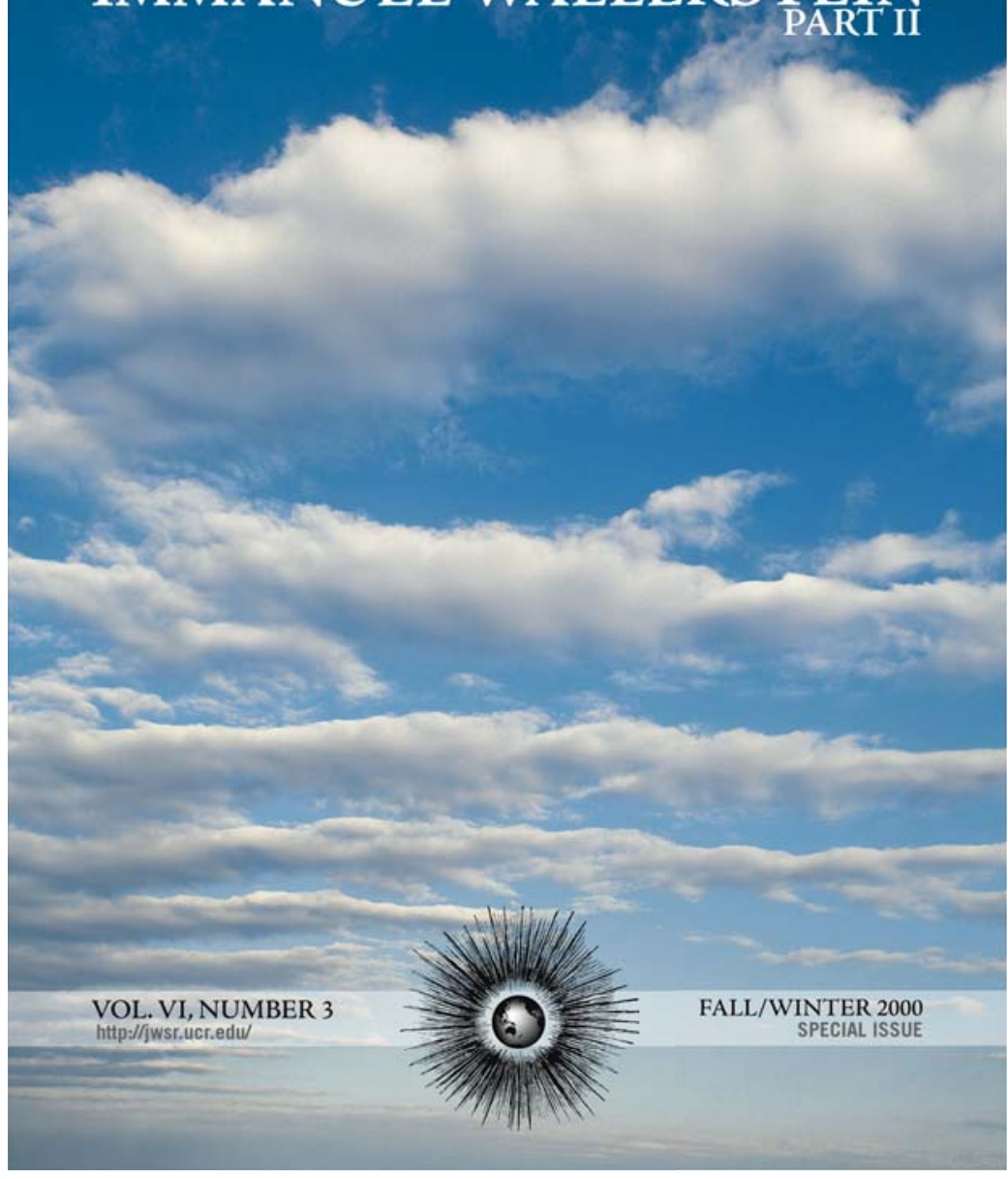

concern for the possible futures of the modern world-system has been $\mathrm{A}_{\mathrm{a} \text { recurrent theme of world-systems analysis. There has, however, been }}$ relatively little effort to think about these futures in terms of democratic theory. In this article, I will explore some of the issues that need to be tackled to take radical and cosmopolitan questions of democracy better into account in world-systems analysis. In particular, I will point out some problems that need to be confronted in the collective process of locating and making visible the politics of "nonpolitical" spaces, such as the ones constituted by transnational business communities and their corporate bureaucracies.

To rely on the meaning of "politics" as something that necessarily deals with state governments is becoming increasingly restrictive in our transnationalizing world. ${ }^{1}$ While this argument as such is hardly original, its spatiopolitical implications for the future of the world-system are frequently left unspecified, referred to only in passing, or hidden under the often deliberately vague terminology of postmodernist suspicion. I intend to explore some of these implications from a viewpoint that assumes the need to search for democratic alternatives to the hierarchical power structures of the capitalist world-system.

Teivo Teivainen

Ibero-American Center at Renvall Institute

PO Box 59, 00014

University of Helsink

FINLAND

http://www.helsinki.fi/hum/ibero/

teivo.teivainen@helsinki.fi

JOURNAL OF WORLD-SYSTEMS RESEARCH, VI, 3, FALL/WINTER 2000, 706-725 Special Issue: Festchrift for Immanuel Wallerstein - Part II

http://jwsr.ucr.edu

ISSN 1076-I56x

(C) 2000 Teivo Teivainen 
I shall argue that to analyze and participate in today's-and especially tomorrow's-transnational political struggles, we need to move beyond exclusively territorialist accounts of social space and focus on the political multidimensionality of the world-system. ${ }^{2}$ We need multiperspectival conceptual maps that help us locate and analyze the formation of overlapping political spaces-be they called "political communities," "political superstructure of the world-system," or something else. The single-perspectival mapping of the world ${ }^{3}$ and the socially constructed dichotomy between "political" and "economic" spaces have all too often seduced us into assuming that territorial states constitute the politics of our world.

Deconstructing the discourse according to which the undemocratic praxis of the "private" transnational corporations and the "strictly economic" global financial institutions is somehow nonpolitical can help undermine their legitimacy. According to the mainstream tradition of western political thought - which many of the leaders of these institutions claim to honordemocracy is a valid norm within the realm of politics. ${ }^{4}$ By showing that the actions of these institutions are by no means beyond the realm of politics, we can at last in principle open up the spaces constituted by their praxis for democratic demands. If our collective immanent critique is taken seriously, it should become clear they have not really honored the principles they have paid lip service to.

This would leave the rulers of the undemocratic institutions with a dilemma. Either they would have to admit that they in fact prefer authoritarian political rule to democracy, or, more ideally, they would have to participate in the democratization of their institutions. The latter possibility is hard to envision, but I think it is possible to at least partially achieve the former one. By focusing on the inherently political nature of the transnational and global "economic" spaces and by insisting on the thereby legitimized need to democratize them, the ideologically empowering banner of democracy may be taken out of capitalist hands. ${ }^{5}$

In terms of constructing democratic futures, my emphasis on formulating arguments to politicize the transnational spaces of power is certainly quite limited. For example, I shall not deal with the crucial issue of political strategies for getting the radically democratic discourses heard in the largely corporate-controlled media networks of the world. My focus will be on the more modest issue of what we should say, or to be more exact, where to look to find adequate categories for mapping our world, with the hope that some of the ideas formulated with these categories might be translated into a language more useful to the political struggles than our academic jargon.

After a rather general overview of how political theories and international relations literature have tended to assume away some politically relevant spatial implications of the transnationalization and deterritorialization processes, I shall pay specific attention to the world-systems approach. I shall argue that in order to face the political and theoretical challenges of the futures of the world-system, the modernist map of political space used by the traditional world-systems approach needs to be redrawn. I use the term "modernist" to refer to the territorialist and single-perspectival conception of social space. I shall conclude with some remarks on the importance of imagining institutional features of transnational futures.

\section{TRANSNATIONALIZATION AND DETERRITORIALIZATION}

In the 1990s, we experienced a proliferation of books and articles that focused on the restrictions that the transnationalization process places on the functioning of democracy within particular nation-states. Even if the majority of the analyses has considered any talk of transnational, global, or cosmopolitan democracy to be hopelessly utopian and therefore irrelevant, this trend in democratic theory has been opening up new debates across the academic walls. There are many reasons for optimism when democratic theories are cross-pollinated with theories of international relations, global economy, or world-systems.

For those of us concerned with working towards a theory of radically democratic praxis and its constraints in the transnationalizing and globalizing world, a simple articulation between existing accounts of the "inside" and the "outside" is, however, not enough. Certain assumptions that are becoming more and more incompatible with today's social processes have been generally shared on both sides of the academic walls. The "modernist" idea of a strict territorial division into internal and external areas as regards particular political spaces is one of them. I shall argue that the analytical usefulness of this kind of spatial categories is being undermined by the twin processes of transnationalization and deterritorialization.

Transnationalization is a process that transgresses the borders of nation-states, and it must be analytically distinguished from globalization 
and internationalization. ${ }^{6}$ Transnational spaces - or "spatial extensions" often have territorial forms, as in the creation of transborder regions that connect geographically close actors across state borders. ${ }^{7}$ In many transnational processes, however, territorial proximity is becoming less important for the definition and explanation of social proximity. Transnational spaces are increasingly assuming deterritorialized-or relatively nonterritorialforms. ${ }^{9}$ This by no means denies the fact that, for example, the main office locations of leading investment banks tend to be concentrated in certain territorially limited areas.

Making the distinction between deterritorialized and territorial forms of space is an important antidote to certain accounts, often but not always postmodernist, in which the crisis of territorialist categories has been misleadingly interpreted as a growing irrelevance of space per se. ${ }^{10}$ Nevertheless, the distinction should not be interpreted in too dichotomous terms. ${ }^{11}$ It is rather a question of degree, and deterritorialized spaces certainly maintain many territorial links, ${ }^{12}$ even if they cannot be defined by any coherent territory that they cover. A deterritorialized space is not necessarily less material than a territorial space, ${ }^{13}$ and - what is more relevant to my argument-it is by no means inherently less political.

According to Robert David Sack's useful formulation, territoriality is "the attempt by an individual or group to affect, influence, or control people, phenomena, and relationships, by delimiting and asserting control over a geographic area." ${ }^{14}$ Furthermore, when metaphorical spatial concepts are booming in social theory, it needs to be specified that territorial area is a space with boundaries that are relatively coherent from the viewpoint of a "normal," two-dimensional map. ${ }^{15}$ In a deterritorialized space, such as the Internet or transnational financial networks, the actors are effectively tied together, even if it is difficult or impossible to locate any coherent space formed by their links on a flat-surface map.

It is often assumed that late modern processes are limited to the "already developed" west, and have little relevance for analyzing the "still developing" areas of the world. Even if there certainly are many differences and inequalities in terms of power and material resources between different areas of the world-system, ${ }^{16}$ this assumption is somewhat misleading. For example, some of the so called post- or late modern characteristics of the western world may have been part of the Third World reality for a long time. Deterritori- alization is one of such features, and its newness has been insightfully questioned, among others, by the Latin American Subaltern Studies Group:

'de-territorialization' of the nation-state under the impact of the new permeability of frontiers to capital-labor flows merely replicates, in effect, the genetic process of implantation of a colonial economy in Latin America in the sixteenth and seventeenth centuries. ${ }^{17}$

To the extent that this "postmodern" spatial phenomenon is a replication of some "early modern" colonial experience, ${ }^{18}$ we are faced with a problem in our temporal frameworks. When "we," in the North, have been accustomed to consider ourselves more developed than "they" in the South are, it should be somewhat confusing to find out that what seems so new to us might actually be an old story for them. The recent intensification of the transnationalization and deterritorialization processes and their disturbing implications for the modernist mapping of the world, however, makes it analytically useful to define them as late modern characteristics of the world-system, even if their newness should not be exaggerated. ${ }^{19}$

One historical example of relatively nonterritorial systems of rule were certain "primitive governments," where the spatial extensions of rule were demarcated on the basis of kinship, and not defined by territory. ${ }^{20}$ The recent intensification of transnational migration is accompanied by a reemergence of political demands for systems of rule that are based on ancestral origins or skin colour, and not on inhabitancy within a territory. These claims have existed for a long time, but the magnitude of transnational and transcontinental flows of people is becoming such that the immigrants, often with few democratic rights, cannot for much longer be regarded as insignificant anomalies for the state system and the corresponding definitions of citizenship based on mutually exclusive territorialities.

The transnational flows of people are still rather insignificant - though probably having a spectacular increase in the future-when compared to the mobility of capital. Some of the most obvious examples of the late modern features of social space can indeed be found in the realm of transnational capital flows. The computerized and globalized networks where capital, especially finance capital, ${ }^{21}$ moves, have in many ways created deterritorialized spaces within the world-system. ${ }^{22}$ Contrary to the claims of Richard O'Brien, Chief Economist of the American Express Bank, these changes by no means signal "the end of geography" in the finance and investment busi- 
ness. ${ }^{23}$ What they do signal is the crisis of single-perspectival territorialist accounts of the spatial units of the world.

Even if it is today almost a truism to say that financial transactions increasingly escape territorial borders, the fact that these transactions also constitute systems of rule is largely ignored or assumed away. In most theories of democracy, systems of rule are tightly contained within the theoretically privileged political communities called nation-states. Between and beyond these territorial containers, in the realms of global economy or international relations, there supposedly exists either a space of nonpolitical economic transactions ${ }^{24}$ or an anarchy where politics is assumed to be somehow less authentic than within the territorial states. ${ }^{25}$ The pursuit of political goals such as democracy is thereby assumed to be possible only within the "public" sphere of national governments.

Transnational corporations and global financial institutions cannot be regarded as direct substitutes for the interstate system, but because of their flourishing production of normative discourses and authoritative control over capital flows, many of them can be regarded as communities, or at least communities-in-the-making ${ }^{26}$ Many critical social movements are also organizing transnationally, though generally to a much smaller degree than the business elites. These transnational linkages increasingly include processes that create feelings of belonging together, which is producing deterritorialized communities within, to name a few examples, labor movements, "gay nations," religious organizations, and antinuclear coalitions. Many of these linkages are undoubtedly created on a short-term, ad hoc basis, and could well be described as loose advocacy networks. ${ }^{27}$ Some are, however, producing communities that will have longer-term effects and increase the political multidimensionality of the world-system.

One of the traditional yardsticks of the state as a political communitythe means of violence-is undoubtedly still very much under state control. It remains to be seen to what extent transnational nonstate actors will be able to have their own enforcement troops. I would suggest that a Robocop3-like scenario, where a transnational (Japanese) corporation uses its own police forces to control riots in a "foreign" territory (Detroit, largely owned by the corporation), is a reasonably plausible vision of the future. A significant increase in terrorist actions by (quasi)religious groups that cannot be located in any coherent territory is another possible future that should not be underestimated.

\section{RETHINKING THE WORLD-SYSTEMS APPROACH}

The world-systems approach-defined at this point as its Wallersteinian version ${ }^{28}$ - provides us with many tools that help us locate and analyze global as opposed to national praxis. Through its attempt to break free from the territorial boundaries of the central object of social science-the national society - the world-systems approach has greatly enriched our spatial imagination. Besides the direct contributions of the approach in building a conceptual framework, its appearance in the mid-1970s had an impact that has ever since encouraged nation-state-centered theories to confront the globalization problématique.

Even though I shall argue that the traditional world-systems scheme of Wallerstein is based on some problematic assumptions about the political/ economic boundary, I disagree with André Drainville, who mistakenly argues that in world-systems theory the world economy is conceptualized "simply as a bridge between national social formations." To prove his argument, he quotes Wallerstein as saying that "[to] be 'social' [is] to be 'national'."29 In fact, Wallerstein was referring to the strategies of the great social revolutions of the twentieth century, in which " $t \mathrm{t}]_{\mathrm{o}}$ be 'social' they had to be 'national'." A few lines below the misquoted statement, Wallerstein expresses his own view: "The capitalist world-economy as a totality-its structure, its historical evolution, its contradictions-is the arena of social action." ${ }^{30}$

By emphasizing the continuities of the modern world since the so called long sixteenth century, the world-systems approach has been an invigorating antidote to the excesses of the new-global-world vision of many globalization theorists. A somewhat stubborn insistence on "it's all business as usual" may, however, also imply an analytical straightjacket. Globalization as such is not as new as some would make us believe, but there are changes occurring in the late twentieth century that demand an analytical sensitivity that sometimes tends to disappear in the long-term structuralism of the worldsystems approach. ${ }^{31}$ In other words, the "modern" world-system analyzed by Wallerstein might be transforming itself into a "late modern" world-system, 
and if so, some of the modernist baggage in the Wallersteinian framework needs to be transgressed. ${ }^{32}$

The incongruity of the present world-system with modernist spatial categories is due more to the transborder character of much social interaction than to the global reach of the system. In much of the recent literature that deals with the globalization process, there exists an implicit or explicit division into two discrete dimensions of it: scope and intensity. Globalization becomes, somewhat tautologically, global in scope when it operates world-wide. Its intensity refers to the intensification in the levels of interaction, interconnectedness, or interdependence. ${ }^{33}$ This distinction as such is a useful analytical tool, but it becomes problematic when it is assumed that only the former process has spatial implications. It tends to be forgotten that the intensification of transnationalization, as opposed to internationalization, creates spatial extensions that break the picture of social space divided into mutually exclusive territorial containers.

Even if world-systems analysis has focused on many transnational processes in a more sophisticated way than most of the recent theories of globalization, it has been less successful in theorizing the political relevance of transborder flows than in analyzing the world-wide scale of the social division of labor. This is perhaps most obvious in the spatial division of "one worldeconomy" into "multiple political units." The multiple political units form the "political superstructure" of the world-economy, and they are exclusively defined as "sovereign states." ${ }^{34}$ Even though this division is not necessarily always regarded as an absolute one, the categories imply an understanding of politics as something that happens within specific territorial containers. Correspondingly, transnational processes have been approached through unnecessarily depoliticized theoretical lenses.

By emphasizing that the modern capitalist world-system is by definition a world-economy, the world-systems approach has been vulnerable to accusations of economistic bias. ${ }^{35}$ The view that the Wallersteinian concept of world-economy can be interpreted as referring to a social system in a wider sense, and not only to the "economy" of standard economics or everyday language, is generally not taken into account by critics. The confusion is often increased by writing world-economy (or world-system) without the hyphen. The difference implied by the apparently insignificant hyphen is perhaps clearest in the romance languages: économie mondial vs. économie- monde or economía mundial vs. economia-mundo. The latter, hyphened terms imply a rather holistic unit ("world," which could perhaps be used synonymously with "social space"), whereas the former ones are practically synonymous with "global economy."

The ambiguity is increased by the fact that Wallerstein sometimes does use the term world-economy to refer to the standard understanding of "economy."36 Somewhat in passing, he has noted that conceptualizing the "effective social division of labor" as an "economy" is "code language," 37 which, I would suggest, translates to a need for an uncoding of world-systems terminology. As with most of the theoretical problems implicit in the worldsystems approach, an important part of this problem of rigid categories has been noticed and emphasized by Wallerstein himself:

Theoretically, the issue is simple. Everyone in the social sciences uses regularly the distinction of three arenas: the economic, the political, and the sociocultural. No one believes us when we say there is but a single arena with a single logic. Do we believe it ourselves? Some of us, no doubt, but not even all of us. And all of us fall back on using the language of the three arenas in almost everything we write. It is time we seriously tackled the question. ${ }^{38}$

Tackling this question, unthinking this nineteenth-century holy trinity, ${ }^{39}$ is certainly an urgent and difficult task. For reasons of clarity, I focus on the implications of the dichotomy between "political" and "economic" arenas. To separate the category of economy, even in the more nuanced version of "world-economy," from the category of politics, is to prevent oneself from analyzing the always political nature of what the apologists of capitalism have wanted us to regard as technical, apolitical and natural issues. ${ }^{40} \mathrm{I}$ do not attempt to find a satisfactory solution to the problem of the "language of the three arenas" here, ${ }^{41}$ but would instead like to point out that tackling the problem has consequences for the spatial framework of the world-systems approach. ${ }^{42}$

To simply replace the problematical concepts of the "three arenas" with new ones and continue as if nothing else needed to be rethought would clearly be a nonsolution. If we take Wallerstein's invitation to "unthink" seriously and accept that it is not useful-not even for the sake of theoretical exposition-to characterize the bureaucracies and power-networks of the transnational corporations as somehow less political than state bureaucracies, we need to question the assumption that territorial states exclusively 
constitute the multiple political units of the world system. There indeed are many reasons to claim that "private" transnational corporations are no less political than "public" state institutions. ${ }^{43}$ The fact that the dominant version of liberal discourse tries to construct a dichotomous theoretical wall between the private corporation and the public state is understandable because of the generally accepted view according to which democratic claims are not valid within the private sphere. For a radically democratic theory, it should be obvious that this wall has to be deconstructed.

The praxis of the capitalist corporations disguised under the discourse of economic neutrality needs to be analyzed as political praxis. To the extent that this praxis is transnational and it constitutes social spaces such as transnational business communities, we need to account for transnational political units as parts of the "political superstructure" of the world-system. ${ }^{44}$ This by no means implies that the interstate system would be withering away very soon, ${ }^{45}$ or that it would have no specific characteristics that distinguish it from other power networks of the world-system. Nevertheless, marking the distinction between states and transnational corporations with the politicaleconomic dichotomy is highly problematic. Emphasizing the territoriality of the states would be a more useful way of distinguishing them from transnational and deterritorialized political spaces.

The territoriality question has not been left totally unanalyzed by the world-systems approach. In their book on antisystemic movements, Arrighi, Hopkins and Wallerstein do pay close attention to the "transterritorial economic command" of the transnational corporations and distinguish it from the "typically 'territorial" political command of the states ${ }^{46}$ It is, however, too simplistic to reduce the power-effects of the transnational corporations to the category of "economic command" as opposed to "political command." This reduction diminishes our ability to analyze their political praxissuch as media control, production of normative discourses, authoritative planning of intrafirm trade, political use of investment strikes, and also the possibly increasing reliance on their own enforcement troops. ${ }^{48}$

The dichotomy between "political command" of the state and "economic command" of the corporations will probably become more problematical in the future, if the state bureaucracies, by becoming business-like, will increasingly be following an "economic" logic, and if large business organizations will increasingly assume functions that have at least in principle belonged to the state. As regards the labor force, transnational corporations can assume state-like functions for example by providing pensions, child care, health insurance, job security, seniority systems, and procedural "citizenship" rights for their workers. ${ }^{49}$ By assuming that the territorial mosaic constituted by states is all there is to the "political superstructure" of the world-system, the political multidimensionality of the late modern world-system is all too easily overlooked.

The analysis of the "long twentieth century" by Giovanni Arrighi is a fruitful attempt to break some of the spatial rigidities of the traditional world-systems approach. His distinction between the "space-of-places" of state governments and the "space-of-flows" of business organizations corresponds to a certain extent to the distinction between territorial and deterritorialized space..$^{50}$ In his framework, the division of the world-economy into "competing political jurisdictions" is regarded as somewhat more contingent and less absolute than in the traditional world-systems approach. By acknowledging that "[state] form of territoriality as the basis for organizing political life seems to be torn apart by a non-territorial, functional space," ${ }^{51}$ Arrighi is able to transcend much of the territorialist bias of the traditional world-systems approach-even if some of his statements still seem to rely on a rather depoliticized understanding of economy. ${ }^{52}$

To what extent the transnationalization and deterritorialization processes have by now decreased the usefulness of the modernist and territorialist spatial framework of world-systems analysis should, of course, also be analyzed empirically. My generalizing analysis has certainly overlooked, for example, the differences between various kinds of transnational corporations, or various kinds of states. Depending on the indicators, I might be accused of overemphasizing the late modern characteristics of the worldsystem, and it might even be difficult for me to deny all the charges. In terms of the future of the world-system, however, the relevant question is whether the late modern processes under analysis in this article will continue and intensify. My conceptual critique has been encouraged by the prediction that they will.

\section{INSTITUTIONAL FEATURES OF TRANSNATIONAL FUTURES}

My focus on how to politicize and undermine the spaces of corporate power has one further limitation, perhaps the most crucial one. Beyond 
deconstruction, we need reconstruction. In many of the most innovative approaches to late modern transnational politics, such as William Connolly's, the political prospects of "multifarious spatialization of democratic energies" are projected in terms of "democratic politics of disturbance." 33 Disturbance is good, when directed at unaccountable power, or at our own inadequate categories. To make the unaccountable accountable, however, we need to imagine institutional features of possible futures.

One probable explanation for the reluctance of many critical minds to engage in the imagining of institutional features of transnational futures, is that institutional aspects have been the bread and butter of theorists working with restricted notions of formal democracy. The radical liberation of democratic imagination is often conceptualized in terms of "authentic" or "participatory" democratic processes as opposed to the "formalist" or "electoralist" models of democratic institutions. I certainly think that democratic theory and praxis should indeed emphazise popular participation. Democracy, however, is about forms of rule, and an outright rejection of "formalism" may imply throwing the baby of defining radical forms of democratic accountability out with the bathwater of conservative attempts to imprison democracy within the national and territorial imagery of the "public sphere."

The political usefulness of formulating models of transnational, cosmopolitan, or global democratic institutions of the future is not only that they can provide inspiration for those who might struggle for their realization. Such models are also important for the deconstructive politics of undermining the existing networks of power, because the legitimacy of the latter, especially after the "victory of democracy over totalitarianism," is largely based on the there-is-no-alternative discourse. In this sense, deconstruction and reconstruction are two sides of the same coin.

I would like to share a personal experience to illustrate the political relevance of imagining democratic models of transnational futures. In an otherwise boring seminar on a dark and cold winter morning in Helsinki, ${ }^{54}$ I had an exchange of opinions with a charming French gentleman named Michel Camdessus, whose job is to manage and direct the International Monetary Fund. His discursive strategy was an example of, on the one hand, the attempts of the rulers of our world to deny that they might somehow break the norms of democracy and, on the other hand, when the denial becomes impossible, to point to the lack of alternatives.
When I asked about the lack of democratic accountability in the IMF, Camdessus categorically denied the charge. "In the IMF, we have a high degree of democracy." He could, of course, have used the discourse of economic neutrality to deny the relevance of the democratic norm in the "nonpolitical" IMF. But he did not, perhaps because the political role of the IMF in the system of global governance had become quite obvious even in the speech delivered by him a few minutes earlier.

It was not particularly difficult to argue that Camdessus was wrong. The degree of democracy in the IMF-governed by the one-dollar-onevote principle-is about as high as the temperature was in the streets of Helsinki on that particular winter morning. Therefore, he had to switch to another discursive strategy. "Look at the alternative. The United Nations General Assembly is governed by the democratic principle of one country one vote. Would it not be absurd, if Fiji and Monaco had the same voting power in the IMF as the United States has?" After these words, he left the stage, amidst applause, smiling.

It would certainly be somewhat ridiculous to claim that true democracy on the global level could be achieved by giving to "Fiji" and "Monaco" the same voting power than to "the United States." Correspondingly, most participants in the seminar were probably convinced that a democratization of the IMF would indeed be quite absurd. In our collective imagination, there was no democratic alternative in matters of global governance, because it was easy to see the democratic deficit of the only existing alternative, the one-country-one-vote model.

If the participants had read a book such as W. Warren Wagar's Short History of the Future, which describes a future world-system where global institutions are governed by popularly elected delegates, roughly corresponding to the one-person-one-vote principle, the atmosphere in the seminar room might have been different. ${ }^{55}$ It might have been more difficult for Camdessus to delegitimize the delegitimizer, to deconstruct the deconstructive argument by using the there-is-no-alternative discourse.

The relevance of the "commonwealth" model envisioned by Wagar is not that it would necessarily be the most feasible or even desirable blueprint for a radically democratized world-system of the future. ${ }^{56}$ In the model, the system of global governance is based on a projection of a territorial state on the global level. It assumes a spatial homogeneity between a modern nationstate and the world state, except that the latter is bigger than the former. ${ }^{57}$ 
It overlooks the possibility of finding transnational forms of democratic accountability that are not defined by territories they cover. In the Commonwealth World, the capitalist "megacorps" have been consolidated into democratically controlled state corporations. ${ }^{58}$ If we assume that some of these corporations extend transnationally, we could, and in my opinion should, also imagine transnational nonstate forms of democratic accountability.

For example, the corporations could be controlled by their workers' transnational assemblies, perhaps together with other people most directly affected by the issues the corporations deal with. In a parallel fashion, we could claim that communities affected by a particular state's actions should have a say in its decisions, even if they do not live within its borders or belong to its citizenry. Of course, it can be difficult to define the boundaries of such communities if they cannot be located in any coherent territorial area. This difficulty makes it convenient to rely on territorial units when trying to imagine democratic futures. Nevertheless, the apparent convenience of confining democratic accountability within territorial containers should not prevent us from imagining less territorialist models of democracy. ${ }^{59}$

The importance of Wagar's achievement, and that of the very few other models of global democracy, should not be dismissed because of their problems and ambiguities. ${ }^{60}$ Their relevance should be seen in terms of opening up an emerging political space, constituted by those of us who want to engage in and identify themselves with the collective project of building such models. The multiplication and proliferation of the models will help us undermine the there-is-no-alternative discourse and thereby empower us to engage in "politics of democratic disturbance" beyond the limits set by postmodernist scepticism. At the same time, of course, they will empower us to imagine possible futures. Imagine, in order to construct.

\section{ENDNOTES:}

1. On the confusion between different understandings of "politics," see Roberto Unger, Social Theory: Its Situation and Its Task (Cambridge: Cambridge University Press, 1987), pp. 145-146. For him, the narrow meaning of "politics" can be stated as "conflict over the mastery and uses of governmental power." To analyze the politics of practices and spaces other than those directly related to state governments, it is more useful to rely on the broader meaning, which he defines as "struggle over the resources and arrangements that set the basic terms of our practical and passionate relations."

2. On how an emphasis on the spatial dimension can lead to "mystique of spatiality" in radicalized sociopolitical analyses, see David Slater, Territory and State Power in Latin America (Houdsmills: Macmillan), p. 10. The same phenomenon can also be found in more mainstream analyses of globalization, where it often misleadingly seems that 'globalized spaces' somehow become actors that have causal effects. See also David Slater 1989, 'Peripheral Capitalism and the Regional Problematic'. in Richard Peet and Nigel Thrift (eds.), New Models in Geography: The Political-Economy Perspective (London: Unwin Hyman, 1989), pp 267-294; and the critical remarks on "making a fetish of the spatial" in John Urry, 'Social Relations, Space and Time', in Derek Gregory and John Urry (eds.), Social Relations and Spatial Structures (Houndsmills: Macmillan, 1985), pp. 20-48. In my approach, space is considered a product of social relations, and it has no causal effects of its own.

3. For a postmodernist account of the "modernist orthodoxies of perspectival space imposed by compasses and charts," see Timothy W. Luke, 'Discourses of Disintegration, Texts of 'Transformation: Re-Reading Realism in the New World Order', Alternatives 18 (1993): 229-258. For a more balanced account that highlights the relativist dilemmas of postmodern criticism of the "tyranny of perspectivism" while recognizing the weaknesses of modernist mapping of the world, see David Harvey, The Condition of Postmodernity (Oxford: Basil Blackwell, 1989).

4. The normative basis of democratic politics is the principle that people should be able to make systems of rule that affect their lives accountable to themselves.

5. For innovative contributions to the strategy of using the modern democratic tradition to critizice the antidemocratic capitalist praxis, see Chantal Mouffe,"Democratic Politics Today', in Chantal Mouffe (ed.), Dimensions of Radical Democracy (London: Verso, 1992); Ernesto Laclau and Chantal Mouffe, Hegemony and Socialist Strategy: Towards a Radical Democratic Politics (London: Verso, 1985); Samuel Bowles and Herbert Gintis, Democracy \& Capitalism: Property, Community, and the Contradictions of Modern Social Thought (New York: Basic Books, 1986). From my perspective, these approaches, usually labeled as radical democratic, are too nation-state-centered and do not pay enough attention to the spatial implications of transnationalization and deterritorialization.

6. In my terminology, globalization is synonymous with transnationalization, except for the assumption in the former term that the transnational processes have a global reach. Therefore all globalization is transnationalization, but not necessarily vice versa. In some of the recent globalization literature, transnational processes tend to be interpreted from an unnecessarily totalizing and homogenizing perspective. Internationalization is a more narrow term, and refers to relations between states.

On effective distance as opposed to "simple geographical distance," see Malcolm Waters, Globalization (London: Routledge, 1995). This is, of course, a rather narrow usage of the term "geographical." One example of territorial transborder regions is the growth of maquiladora industries near the US-Mexican border, though they are certainly also part of the deterritorialized networks of transnational capital. On the "existential uprootedness" of the maquiladora workers, see Primitivo Rodriguez,"The Uprooted from the Land', in 
Jeremy Brecher et al. (eds.), Global Visions: Beyond the New World Order (Boston: South End Press, 1993), pp. 295-298.

8. See Zdravko Mlinar, 'Individualization and Globalization: The Transformation of Territorial Social Organization', in Zdravko Mlinar (ed.), Globalization and Territorial Identities (Aldershot: Avebury, 1992), esp. p. 25.

9. Even if "deterritorialized" should strictly speaking refer to spaces that have previously been territorial, I extend its usage to cover also those relatively nonterritorial spaces that have no "territorial history," such as the Internet. Therefore, "(relatively) deterritorialized" is synonymous with "(relatively) nonterritorial."

10. See e.g. Waters, p. 3, who claims that a globalized world will be "a society without borders and spatial boundaries ;" and Luke, p. 240, for whom flows are despatializing.

11. See e.g. John Gerard Ruggie, 'Territoriality and Beyond: Problematizing Modernity in International Relations', International Organization (47, 1, 1993): 129-174, who refers to a "nonterritorial 'region' in the world economy" (my emphasis), which, if taken literally, is an exaggeration. See also a response to Ruggie, which shows that "home country control" plays an important role in the "extranational" activities of banks. Ethan B. Kapstein, 'Territoriality and Who is 'US'?', International Organization (47, 3, 1993): 501 503.

12. On how "capitalism is continually reterritorializing with one hand what it was deterritorializing with the other" and on the "tension within the geography of accumulation between fixity and motion," see, respectively David Harvey, The Condition of Postmodernity, pp. 236-239; David Harvey, 'The Geopolitics of Capitalism', in Derek Gregory and John Urry (eds.), pp. 128-163. On the continued geographic concentration of corporate headquarters in the dominant cities of the most powerful capitalist nations, see Robert W. Cox, 'Global Perestroika', in Ralph Miliband and Leo Panitch (eds.), Socialist Register (London: The Merlin Press, 1992), pp. 26-43; Roger Friedland and Deirdre Boden, 'NowHere: An Introduction to Space, Time and Modernity', in Friedland and Boden (eds.), NowHere: Space, Time and Modernity (Berkeley: University of California Press, 1994), pp. 1-59, who synthesize their argument with the-somewhat dichotomous - notion that " $[\mathrm{w}]$ hile capital has conquered space and time, capitalists have not."

13. On this point, I disagree with Luke, p. 240, who claims that deterritorialized flows are dematerializing forces. One sad example of the materiality of the largely electronified networks of deterritorialized spaces is that in 1990 the electronics industry contributed to $45 \%$ of the world's CFC output. See Greenline (August 1991).

14. Robert David Sack, Human Territoriality (Cambridge: Cambridge University Press, 1986), p. 19. For various meanings of the concept of territoriality in recent political and industrial geography, see Philip E. Steinberg, 'Territory, Territoriality and the New Industrial Geography', Political Geography (13, 1, 1994): 3-5.

15. This in many ways "down-to-earth" specification is important, because of the recent vogue in social theory to use spatial metaphors in such ways that almost anything can be conceptualized as "field,"' area,"'territory" etc. On spatial metaphors, see Neil Smith, 'Geography, Difference, and Politics of Scale', in Joe Doherty et al. (eds.), Postmodernism and the Social Sciences (Houndsmills: Macmillan, 1992), pp. 57-79; Neil Smith and Cindi
Katz, 'Grounding Metaphor: Towards a Spatialized Politics', in Michael Keith and Steve Pile (eds.), Place and the Politics of Identity (London: Routledge, 1993), pp. 67-83. See also Hervé Théry and Roger Brunet,'Territoire', in Brunet et al. (eds.), Les mots de la géographie: dictionnaire critique (Montpellier: Reclus, 1992), pp. 435-436.

16. An interesting question, which I can simply mention here, is to what extent the core, semiperipheral and peripheral areas of the world-system are territorially bounded.

17. Latin American Subaltern Studies Group, 'Founding Statement', in John Beverley and José Oviedo (eds.), The Postmodernism Debate in Latin America (Durham: Duke University Press, 1993), pp. 110-121. To be exact, nation-states as such are not being deterritorialized, because they are by definition territorial units.

18. There certainly is more to the deterritorialization process today than a "mere replication" of colonial experience. For an analysis of the differences between the seventeenth and eighteenth century joint stock chartered companies, which specialized territorially, and the present-day transnational corporations, which specialize "functionally," see Giovanni Arrighi, The Long Twentieth Century (London: Verso, 1994), pp. 73-74.

19. See also Jussi Pakkasvirta and Teivo Teivainen, 'La crisis de las utopías nacionales en América Latina', IberoAmericana: Nordic Journal of Latin American Studies vol XXVII: 1-2 (1997), 7-21.

20. See Ruggie, p. 149; Sack, pp. 6-9.

21. For a convincing argument that it is precisely the shift in the form of capital, from productive capital to capital held in the form of money, that is producing a change in the relation between the territorially fixed nation-states and the global movement of capital, see John Holloway, 'Global Capital and the National State', Capital \& Class (No. 52, 1994): 23-49. For a historically long-term analysis along the same lines, see Arrighi.

22. See Ruggie, p. 172, who defines the "nonterritorial 'region' in the world economy" as a decentered yet integrated space-of-flows, operating in real time, which exists alongside the spaces-of-places that we call national economies."

23. Quoted in Richard Barnet and John Cavanagh, Global Dreams: Imperial Corporations and the New World Order (New York: Simon \& Schuster, 1994), pp. 396-397.

24. In their analysis of capitalist economy as a system of governance, Bowles \& Gintis, p. 65, quote economist Abba Lerner's article in American Economic Review (1972) as a representative example of the neutrality assumption behind liberal economic theory: "An economic transaction is a solved political problem. Economics has gained the title of queen of the social sciences by choosing solved political problems as its domain."

25. On how the principle of state sovereignty "implies a fundamental distinction between a locus of authentic politics and a mere space of relations between states," see R.B.J. Walker, Inside/Outside: International relations as Political Theory (Cambridge: Cambridge University Press, 1993), p. 20.

26. I have analyzed the political-community-likeness of states vs. transnational and global units in Teivo Teivainen, 'Globalization of Economic Surveillance: The International Monetary Fund as a Modern Priest', Passages: Journal of Transnational and Transcultural Studies, 1, 1 ,1999). 
27. See Margaret E. Keck and Kathryn Sikkink, Activists Beyond Borders (Ithaca: Cornell University Press, 1998).

28. My reading of Wallerstein's approach is here mostly based on his theoretically and politically oriented books and articles rather than his magnum opus. One of the reasons is that the Modern World-System concentrates on earlier centuries, and my focus is on more recent changes.

29. André Drainville, 'Of Social Spaces, Citizenship, and the Nature of Power in the World Economy', Alternatives (20, 1995): 54,

30. Immanuel Wallerstein, The Capitalist World-Economy (Cambridge: Cambridge University Press, 1979), p. 230.

31. This is not to deny that Wallerstein finds many new features in the present stage of the world-system, such as the increasingly chaotic, as opposed to deterministic, nature of social processes, which is linked to the decreasing amount of new space (territory) for the expansion of capitalism.

32. Wallerstein has indeed characterized the present "era of disintegration of the capitalist world-economy" as something that is following the "era of modernity." Immanuel Wallerstein, 'The Collapse of Liberalism', in Ralph Miliband and Leo Panich (eds.), pp. 106-107. It is therefore somewhat surprising that the spatiopolitical categories of his approach are still framed in fairly modernist and territorialist ways.

33. See David Held and Anthony McGrew, 'Globalization and the Liberal Democratic State', Government and Opposition (28, 2, 1993): 261-288.

34. Immanuel Wallerstein, Geopolitics and Geoculture (Cambridge: Cambridge University Press, 1991), p. 107.

35. e.g. Anthony Giddens, The Consequences of Modernity (Cambridge: Polity Press, 1990), pp. 68-70.

36. e.g. Wallerstein, The Capitalist World-Economy, pp. 272-273; Wallerstein, Geopolitics and Geoculture, p. 191.

37. Immanuel Wallerstein, The Politics of the World-Economy (Cambridge: Cambridge University Press, 1984), p. 2.

38. Immanuel Wallerstein, Untbinking Social Science (Cambridge: Polity Press, 1991), p. 271.

39. Wallerstein ibid., p. 4; Immanuel Wallerstein, 'Beyond Annales?', Radical History Review (No 49, 1991): 7-15.

40. On how political science as a separate discipline has legitimated economics as a separate discipline, see Wallerstein, Immanuel et al, Open the Social Sciences. Report of the Gulbenkian Commission on the Restructuring of the Social Sciences (Stanford: Stanford University Press, 1996), pp. 19-20.

41. For an insightful and meticulous deconstruction of the category of the "economic," within broadly defined historical materialism, see Michael Ryan, Marxism and Deconstruction: A Critical Articulation (Baltimore: The Johns Hopkins University Press, 1982).

42. An interesting effort to deal with these problems has been provided by Kurt Burch, 'Invigorating World-Systems Theory as Critical Theory', Journal of World-Systems Research, http://jwsr.ucr.edu/Vol 1, No 18, 1995.
Towards a Democratic Theory of the World-System

43. See e.g. Bowles \& Gintis, pp. 64-67.

44. If we deconstruct, or "unthink," the dichotomy between political and economic spheres, the base/superstructure metaphor obviously becomes problematic, epecially if "base" refers to the "economic base." I do not claim that the metaphor necessarily needs to be discarded, because it might be possible to construct a model where material production (or something else) could be referred to as a "base," even if the metaphysical category of "economy" is not used. Of course, the metaphor would still maintain some of its dubiously deterministic connotations.

45. For a somewhat farfetched vision of the future, see Luke, p. 243, who claims that the majority of the nation-states will probably prove to be "no more than varying nominal guises of actual invariant transnational flows."

46. Giovanni Arrighi et al., Antisystemic Movements (London: Verso, 1989), p. 63.

47. If, as Arrighi et al. seem to imply, "political" is by definition "territorial," one part of the conceptual problem is obviously solved. But, if so, why not simply define state power as territorial power, and avoid unnecessarily narrowing the usage of the category of politics?

48. Besides Robocop 3, the possible future in which "we shall see [...] the expansion of private protection armies and police structures [...] by the corporate production structures [...]" has been envisioned by Wallerstein, 'Capitalist Civilization', Lectures as Wei Lun Visiting Professor, Chinese University of Hong Kong, November 19-21, 1991. The implications of this scenario for the "political superstructure" of the future worldsystem are, however, left unspecified in the Wallersteinian scheme .

49. Friedland \& Boden, pp. 13-14.

50. See Arrighi, p. 23, and pp. 33-34. There are, however, differences between Arrighi's definition of territorialism as a logic of power and mine. For example, he emphasizes the acquisition of additional territories in his definition of territorialism more than I do.

51. Ibid, p. 80.

52. Statements like "as networks of accumulation expanded to encompass the entire globe, they became increasingly autonomous from and dominant over networks of power" seem to depolitizice the power of the business organizations-though it is not easy to understand how something could be "dominant over networks of power" and not be a network of power itself. Ibid, p. 86.

53. William E. Connolly, 'Democracy and Territoriality', Millennium (20, 3, 1991): 463-484.

54. The Finnish United Nations Association seminar, December 1994.

55. W. Warren Wagar, A Short History of the Future, rev. ed. (Chigago: The University of Chicago Press, 1992).

56. Wagar himself points to many contradictions of the world-state model, and also envisions its breakdown into a much more decentralized world. See also Teivo Teivainen, 'Universalism and Ambiguousness: Comments on Wagar's Praxis of World Integration', Journal of World-Systems Research, http://jwsr.ucr.edu/, 2,1, 1996.

57. See Walker, pp. 135-136, for the problems of this assumption, which he refers to as "the theme of Gulliver."

58. Wagar, p. 149. It is not clear whether he refers to the world state, or to the 
administrative districts of between 2.5 and 3.0 million people that in his scenario have replaced the nation-states, but this does not really matter for my argument.

59. To what extent the struggles to democratize specific transnational and deterritorialized spaces can succeed if the world as a whole has not been transformed into a relatively democratic place, is a formidable question I cannot but simply mention here. In my vision of a relatively democratized future world-system, some of the institutions would at some point have to be truly global, but this as such does not imply a need for a Wagarian world-state or a Kantian federation of states.

60. One of the most ambitious models of global democracy can be found in David Held, Democracy and the Global Order (Cambridge: Polity Press, 1995). One of the problems in Held's model is that he emphasizes the separation of political and economic interests as a desirable feature of the future, whereas from my radical democratic perspective this separation should be abolished. 